\title{
Social Justice for Public Health: The COVID-19 Response in Portugal
}

\author{
Luís Cordeiro-Rodrigues $(\mathbb{D}$
}

Received: 19 June 2020 / Accepted: 23 September 2020

(C) Journal of Bioethical Inquiry Pty Ltd. 2020

\begin{abstract}
The COVID-19 pandemic requires emergency policies to be put in place in order to avoid a global health catastrophe. At the same time, there has been an increasing preoccupation that argues urgent policies for public health neglect social justice. By looking at Portugal's successful confinement case during the early stages of the pandemic, I argue that ethically driven social justice policies are not just compatible but also an instrumentally important element in addressing this pandemic in an effective way. The Portuguese case study suggests that enhancing social justice towards socio-economically vulnerable groups correlates with the prevention of the spread of COVID-19; these benefits to public health can be explained by the fact that those policies create social distancing and less exposure to the COVID-19 virus and other contagious diseases and also remove disincentives to the use of healthcare services.
\end{abstract}

Keywords Portugal · COVID-19 - Social justice · Prisons · Immigrants · Domestic violence $\cdot$ Economic austerity $\cdot$ Public health

\section{Introduction}

The economic crisis of 2008 strongly impacted the Portuguese economy, with the centre-right government

L. Cordeiro-Rodrigues $(\square)$

Department of Philosophy, Yuelu Academy, Hunan University, Changsha, People's Republic of China e-mail: 1ccmr1984@gmail.com that won the 2011 elections imposing significant austerity measures and cuts to public institutions, including the national public health services (Weeks 2019). Although the centre-right coalition won the election again in 2015, they were unable to form a government because the three main left-wing parties had a parliamentary majority and made a semi-coalition; this enabled the Socialist Party to govern and avoid any further economic austerity from centre-right parties (Finn 2017). António Costa-leader of the Socialist Party and Prime-Minister of Portugal-went on to implement a variety of social welfare policies (Finn 2017). The Portuguese response to COVID-19 can, in fact, be understood as a continuation of these social welfare policies that promote social and economic equality amongst different groups. I wish to argue, in this case study analysis, that the social justice measures implemented by the Portuguese government played an important role in effectively promoting public health during the current pandemic. This is the case because these measures contributed to create social distancing and less exposure to COVID-19, reduced the risk of being infected by other contagious diseases, and removed disincentives for avoiding the use of healthcare services. In other words, the existing correlation between Portuguese social justice policies and positive outcomes for public health, which mitigated the spread of COVID-19, can be explained by the fact that those policies allowed and encouraged conditions for more social-distancing to take place, and thereby less infections of COVID-19 and other contagious diseases to occur; further, by providing incentives for the socio-economically vulnerable 
population to use the nation's health services, the policies expedited detection of infections, thereby reducing the probability of an infection spread. This leads me to conclude that promoting social justice is not only a just way of fighting the pandemic but, in fact, can also positively contribute to overcoming it. I conclude that although these measures were important, they could have been more successful if they had been more inclusive and did not neglect other vulnerable individuals, such as the homeless and people with disabilities. I also uphold that the measures to protect precarious workers were insufficient and more should have been done here. Similar arguments have been put forward before (Cordeiro-Rodrigues 2020; Johnstone 2020). Nevertheless, the present study differs from previous work in two ways. Firstly, while previous work explored the links between social justice and public health during the pandemic in an abstract way, the current study looks at specific measures. Secondly, while previous research hypothesized about social justice policies in the context of Africa and Australia, the present study focuses on Portugal.

To forward my argument, I have divided this article into two sections. In the following section, I describe the main social justice policies carried out by the Portuguese government during the pandemic. In that section, I focus mostly on explaining the targets of the policies and the details of the governmental edits. The section after that describes why these policies were instrumentally valuable in promoting public health in the face of the COVID-19 pandemic. I also explain why the policy may not have been successful in other countries which implemented similar policies, by looking at the case of failure in the United Kingdom.

\section{The Portuguese Response to COVID-19: Social Justice Concerns}

The initial predictions indicated that Portugal's situation would be similar to that of Spain and Italy (Observador 2020; Simões 2020). These initial predictions were based on both the shortage of medical supplies and medical human resources (e.g., Portugal initially only held stocks of just over one thousand ventilators), the geographical proximity to highly affected countries, and the fact that Portugal is a tourist destination with significant flows of people from affected areas (Buescu 2020; Observador 2020; Simões 2020). Nevertheless it is now widely agreed that Portugal's decision to use a confinement strategy for the COVID-19 pandemic was a successful one, at least in its initial stage (World Health Organization [WHO] 2020; Le Monde 2020). A variety of explanations for the so-far successful Portuguese performance include the fact that measures for social isolation were taken relatively early, the fact that the Minister of Health, Marta Temido, has substantial experience in health management and public health, the fact that schools closed early, the fact of the country's geographical positioning with only one territorial border, and the politics of massive testing (Le Monde 2020; Smoltczyk 2020; Ames 2020). At the same time, Portugal is an interesting case study because it has not taken the same measures as other countries which have effectively dealt with the COVID-19 pandemic. For example, Portugal has not used phone location data like South Korea, has not closed all its borders very early like the Czech Republic and Austria, nor adopted a radically strict confinement policy like South Korea and Vietnam. This makes the Portuguese case worth analysing at a time where pandemic-response emergency measures may sometimes discard ethical concerns (as has occurred in Hungary) (Singh and Moodley 2020; Fritz et al. 2020).

Many of the reasons above have indeed contributed to the success of Portugal's dealing with COVID-19; nevertheless, the role of the social justice policies implemented by the Portuguese government have not yet been pointed out as reasons for this success, and I contend here that they have actually played an important role. Specifically, Portugal took the approach of protecting some of the most socio-economically vulnerable from being infected and this policy helped to control the spread of infection in the country. The main groups identified by the Portuguese government as the most socio-economically vulnerable and, thereby, most in need of social justice measures to support them have been victims of domestic violence, prisoners, illegal migrants, and precarious workers (Portuguese government 2020a, 2020b). With respect to prisoners, the initial policy was to suspend all visits to prison establishments on the grounds that in these very confined places the spread of COVID-19 could happen exceptionally fast. Later on, the government added to this policy a significant number of sentence pardons for prisoners. All prisoners who had not committed serious crimes (including armed robbery, corruption, homicide, domestic violence, paedophilia, and sexual abuses) and who had a prison sentence of less than two years or were 
in the last two years of their sentence were pardoned and released (Portuguese Government 2020a, 2020b).

Confinement during the pandemic could significantly increase the risk of domestic violence, as the victims would be pushed to spend more time with their aggressors and because confinement itself significantly potentializes stress levels and mental health issues. Hence, a variety of measures were taken to decrease the risks of domestic violence. In particular, there was a reinforcement of the capacity of response to domestic violence cases including maintaining and monitoring help lines, hiring personnel to reinforce these issues, creating an additional helpline, and opening sheltering facilities for victims (Portuguese Government 2020a, $2020 \mathrm{~b}$ ). On top of this, the government established a rule and exemption policy which allowed social distancing measures to be ignored in cases of aid to victims of domestic violence. With respect to illegal immigrants, during the COVID-19 pandemic, they were given full citizenship rights, entitling them to an equal and full use of the Portuguese national health service (Portuguese Government 2020a).

Precarious workers were mostly aided through poverty alleviation measures. As the government was aware that ceasing most commercial activity would cause a substantial amount of poverty, it endorsed some measures to prevent unemployment and bankruptcy. Companies which had to partially or fully cease their commercial activities and whose profits decreased over 40 per cent during the pandemic were deemed exempt from contributions to social security and were able to receive financial support, although only if they kept all their employees during this time. Temporary and precarious workers were entitled to receive a basic income of between 438.81 and 635 euros monthly (the Portuguese minimum wage) for a period of six months (Portuguese Government 2020a, 2020b). In addition, it eliminated a substantial number of costs associated with access to healthcare. Healthcare in Portugal is public rather than private, and Portuguese citizens only pay a symbolic amount (nearly five euros) for visiting a hospital. The Portuguese government reinforced these measures by making health-line phone calls free and exempting those suspected of and infected with COVID-19 from paying the aforementioned symbolic amount or indeed any payment at all for treatment and testing (Portuguese Government 2020a).

\section{The Links Between Social Justice and Public Health}

The positive impact of these policies on reducing the spread of the pandemic can be explained in a number of ways. Firstly, these policies removed the disincentive that many individuals may have had in accessing health services and made the detection of infection faster. The incentives for using healthcare services in the case of a highly contagious disease such as COVID-19 are crucial for containing the disease. Fundamentally, they hasten detection, bearing in mind that any delay of detection can increase the likelihood of exposure which may lead to higher numbers of people becoming infected. Illegal immigrants may have a disincentive to get tested and avoid attending health services for fear of being reported and consequently repatriated. Thus, to the extent that they were given full citizenship rights, whereby these included the right to fully access healthcare services, this mitigated the deportation risk (Euronews 2020; Portuguese Government 2020b). The inclusion of illegal immigrants was especially important because they tend to live and work in places that are overpopulated and without basic sanitation, which potentializes the spread of COVID-19.

Those who are economically disadvantaged (which also includes illegal immigrants) were also incentivized to use health services by the fact that the economic barrier for using these services was removed. Hence, economic measures reassuring the population that testing, treatment, and assistance for COVID-19 was totally free also meant that those people who thought they might have been infected could be tested and treated without worrying about the subsequent healthcare costs. Such incentives diminished the likelihood of leaving those people untreated who could spread the disease. As a matter of contrast, note that in places where there are significant socio-economic differences and high economic costs associated with healthcare, people do tend to delay using health services. For instance, in the United States and Brazil, where healthcare is mostly private, individuals tend to delay seeing a doctor (Lee, HasnainWynia, and Lau 2012; Watts 2016; Terra de Souza et al. 2000); this behaviour in a pandemic with the current characteristics is highly problematic to the extent that it increases the probability of infected people unknowingly spreading the virus and thereby significantly increases the number of people being infected. In short, the Portuguese policy of eliminating economic costs and including illegal immigrants in the system helped 
detection become faster and more widespread, allowing people to have their symptoms treated and thus avoid the further spread of the virus.

The prisoners' sentence pardon and earlier release and the prevention and monitoring of domestic violence facilitated social distancing and, thereby, contributed to keeping the number of COVID-19 and other contagious diseases infections lower. It has consequently allowed the Portuguese public healthcare system, with its rather limited medical equipment and resources, to respond to the pandemic in an effective way. In the case of prisoners' earlier release, note first that prisons tend to be small places confining a large number of people; given the difficulty of maintaining social distancing here, these were places that easily spread COVID-19. Additionally, precisely because of being small, overpopulated places, prisons are also the focus of other contagious diseases, for example, tuberculosis; but by releasing prisoners, the hospital beds, staff, and equipment occupied with potential tuberculosis cases can be freed up. Hence, reducing the number of prisoners helped to promote social distancing and, thereby, avoided the spread not only of COVID-19, but also of other contagious diseases, helping to avoid overloading the healthcare system with its limited resources. Also, notice the contrast with countries containing overpopulated prisons, such as the United States, Brazil, and Russia (Lugo and Wooldredge 2017; MacDonald 2018), where COVID-19 continues to spread rapidly.

The prevention and monitoring of domestic violence measures also had a similar effect in at least two ways. Note first that the profile of domestic violence aggressors is likely to be associated with a variety of other risky forms of behaviour which are likely to increase the spread of COVID-19, such as daily patterns of violence, alcoholism, and the use of prostitutes (Martins and Fiho 2019). All these forms of behaviour involve higher exposure and contact with others and therefore increase the likelihood of COVID-19 infections. By providing sheltering facilities and support to victims of domestic violence, the Portuguese policy helped diminish the number of potentially infected people, not only because potential victims become less exposed to the aggressors who may bring the infection home but also because victims who run away from home will not be homeless, exposed on the streets, and potentially creating a health hazard for themselves and others. In addition to this, such sheltering and monitoring policies mitigate the possibility of aggression and therefore the need for victims to access healthcare, including the beds and resources in hospitals. By diminishing the likelihood of domestic violence victims needing health assistance, the healthcare system is able to alleviate the possibility of overload.

The arguments presented here can be challenged because other countries which have taken similar measures did not have the same positive results. For example, in the United Kingdom, there are no charges for healthcare, some prisoners were released earlier, and immigrants' access to healthcare was also facilitated (GOV.UK 2020; Pakes 2020; London Government 2020; One Pump Court 2020). However, the reason why the same measures may not have worked in the United Kingdom can be explained by looking at other factors. To start with, the U.K. government initially underestimated the importance of the pandemic, taking measures relatively late. The hesitation and general initial hands-off approach of the U.K. government to the problem communicated an unclear and mixed message to the public on how to protect themselves from the virus. Contrastingly, the Portuguese government implemented these measures relatively fast, and there were daily press conferences explaining the high risks of the virus, leading to a clear public information campaign outlining what ought to be done. Moreover, despite facilitating the use of health services for immigrants, the environment for immigrants in a potentially postBrexit United Kingdom is less welcoming, which along with the current economic austerity policies of the Conservative government, may have created some level of distrust, hostility, and confusion with respect to public institutions. Hence, even if these policies were at some point implemented, they were not communicated in a clear manner and may potentially not have been believed to be true, given the generally hostile environment towards immigrants (Duda-Mikulin 2020; Peitz, Dhont, and Seyd 2018; Portes 2020). In addition to this, equality is a complex matter that may require different policies according to the reality of each country or community (Walzer 1984; Phillips 1999). Thus, the specific measures taken by Portugal may make sense given the social reality there, but the existence of various inequalities and vulnerable communities in other countries may require a variety of different measures. On top of this, the implementation of public health policies needs to be culturally sensitive in order to gain public adherence (Weinstock 2014). 


\section{Conclusion}

The Portuguese government's concern regarding social justice contributed to preventing the spread of COVID19 by realizing that lack of social justice, in this situation, would potentially lead to more infections. The lesson taken from the Portuguese case is that social justice matters greatly in terms of public health during this pandemic; however, due to the reasons mentioned above, how social justice is then implemented in each country requires a case by case analysis. It is also important to note that the Portuguese measures could have been more inclusive, especially regarding vulnerable groups. In particular, homeless individuals at special risk were, in broad terms, not the target of special measures. In the case of the homeless, there were no substantial governmental measures to prevent exposure during this period and most of the support offered to them was provided by volunteers, NGOs, and local councils. Likewise, individuals with disabilities have been largely neglected in the measures, and no special measures for them have been taken. Finally, although the economic measures for precarious workers may have saved some jobs, there have also been a substantial amount of redundancies made during this period. To sum up, this case study analysis reveals the importance of social justice for effective public health management, but it not only shows that the Portuguese approach could have been more inclusive and, thereby, more successful but also that in order to become a successful strategy that secures public health, social policies need to be sensitive to the specific characteristics of the country where they are applied and combined with clear public communication and speed in delivery. Further research ought to explore how similar policies can successfully be applied in other countries and what extra measures can be taken in Portugal.

Acknowledgments I wish to thank Francisco Zurita and Simone Roger for their comments on my paper. This research has been funded by Hunan University's Fundamental Research Funds for the Central Universities, fund number 531118010426. 本 文受湖南 大学“中央高校基本科研业务费”专项资金 资助 (531118010426).

\section{References}

Ames, P. 2020. How Portugal became Europe's coronavirus exception. Politico, April 14. https://www.politico. eu/article/how-portugal-became-europes-coronavirusexception/.

Buescu, J. 2020. A matemática que explica o tsunami europeu. E português [The mathematics that explains the European tsunami]. Observador, March 15. 2020. https://observador. $\mathrm{pt} /$ especiais/a-matematica-que-explica-o-tsunami-europeu-eportugues/.

Cordeiro-Rodrigues, L. 2020. Toward a decolonized healthcare ethics: Colonial legacies and the Siamese crocodile. Developing World Bioethics, ePub ahead of print, July 9. https://doi.org/10.1111/dewb.12273.

Duda-Mikulin, E.A. 2020. Gendered migrations and precarity in the post-Brexit-vote UK: The case of Polish women as workers and carers. Migration and Development 9(1): 92110.

Euronews. 2020. Coronavirus: Portugal grants temporary citizenship rights to migrants. March 29. https://www.euronews. com/2020/03/29/coronavirus-portugal-grants-temporarycitizenship-rights-to-migrants.

Finn, D. 2017. Luso-Anomalies. New Left Review 106. https://newleftreview.org/issues/II106/articles/daniel-finnluso-anomalies.

Fritz, Z., R. Huxtable, J. Ives, A. Paton, A.M. Slowther, and D. Wilkinson. 2020. Ethical road map through the COVID-19 pandemic. BMJ 369(8249): m2033.

GOV.UK. 2020. Domestic abuse: Get help during the coronavirus (COVID-19) outbreak. GOV.UK. 2020. https://www.gov. uk/guidance/domestic-abuse-how-to-get-help.

Johnstone, M.-J. 2020. COVID-19: The ethics of solidarity and encouraging responsibility. ANMJ (blog), August 5. https://anmj.org.au/COVID-19-the-ethics-of-solidarity-andits-dereliction/.

Lee, J.C., R. Hasnain-Wynia, and D.T. Lau. 2012. Delay in seeing a doctor due to cost: Disparity between older adults with and without disabilities in the United States. Health Services Research 47(2): 698-720.

Le Monde. 2020. Coronavirus: au Portugal «nous ne savons pas si cela durera un, deux, ou trois mois » [Coronavirus: in Portugal "we do not know if it will last one, two, or three months"]. April 3. https://www.lemonde. fr/international/article/2020/04/03/coronavirus-au-portugalnous-ne-savons-pas-si-cela-durera-un-deux-ou-troismois 6035422 3210.html.

London Government. 2020. Information on coronavirus (COVID19) for non-UK nationals. London City Hall. https://www. london.gov.uk//what-we-do/eu-londoners-hub/informationcoronavirus-COVID-19-non-uk-nationals.

Lugo, M.A., and J. Wooldredge. 2017. Overcrowding in prisons. In The encyclopedia of corrections, edited by K.R. Kerley, 18. https://doi.org/10.1002/9781118845387.wbeoc163.

MacDonald, M. 2018. Overcrowding and its impact on prison conditions and health. International Journal of Prisoner Health 14(2): 65-68.

Martins, A.F. and J.G.B. Fiho. 2019. Can we foretell violence? Predictors of being victim and perpetrator of domestic violence involving children and adolescents in a Brazilian metropolis. Vulnerable Children and Youth Studies 14(3): 259269.

Observador. 2020. Jorge Buescu: "É completamente fantasioso." Portugal não passou ainda o pico da infecção [Jorge Buescu: "It is completely fanciful." Portugal has not yet passed the 
peak of infection]. April 8. https://observador. $\mathrm{pt} /$ programas/resposta-pronta/jorge-buescu-pico-sera-nasegunda-quinzena-de-abril/.

One Pump Court. 2020. COVID-19 and prisons: The coronavirus restricted temporary release scheme, pregnant prisoners and children in custody. News, April 21. https://onepumpcourt. co.uk/news/COVID-19-and-prisons-the-coronavirusrestricted-temporary-release-scheme-pregnant-prisonersand-children-in-custody/.

Pakes, F. 2020. Coronavirus: Why swathes of prisoners are being released in the world's most punitive states. The Conversation, April 20. http://theconversation. com/coronavirus-why-swathes-of-prisoners-are-beingreleased-in-the-worlds-most-punitive-states-136563.

Peitz, L., K. Dhont, and B. Seyd. 2018. The psychology of supranationalism: Its ideological correlates and implications for EU attitudes and post-Brexit preferences. Political Psychology 39(6): 1305-1322.

Phillips, A. 1999. Which equalities matter? Polity.

Portes, J. 2020. After Brexit, Britain's hard line on immigration won't hold. The Guardian, January 29. https://www. theguardian.com/commentisfree/2020/jan/29/brexit-britainhard-line-immigration-openness.

Portuguese Government. 2020a. Comunicado do Conselho de Ministros de 30 de abril de 2020 [Communiqué of the Council of Ministers of April 30, 2020]. https://www. portugal.gov.pt/pt/gc22/governo/comunicado-de-conselhode-ministros? $\mathrm{i}=344$.

- COVID-19: Measures, Guidelines and Recommendations. https://www.acm.gov.pt/-/COVID-19-medidas-orientacoese-recomendacoes.

Simões, S. 2020. "19.303 infetados no fim de março. São estas as contas do matemático Jorge Buescu. [19,303 infected at the end of March. These are the accounts of mathematician Jorge
Buescu]. Observador, March 14. https://observador.pt/2020 /03/14/19-303-infetados-no-fim-de-marco-sao-estas-ascontas-do-matematico-jorge-buescu/.

Singh, J.A., and K. Moodley. 2020. Critical care triaging in the shadow of COVID-19: Ethics considerations. South African Medical Journal 110(5): 355-359.

Smoltczyk, A. 2020. The Portuguese miracle: How Lisbon has managed the corona crisis. Der Spiegel, April 9. 2020. https://www.spiegel.de/international/europe/portugal-howlisbon-has-managed-the-corona-crisis-a-b6e3c7ba-a1724c11-a043-79849ff69def.

Terra de Souza, A.C., K.E. Peterson, F.M.O. Andrade, J. Gardner, and A. Ascherio. 2000. Circumstances of post-neonatal deaths in Ceara, Northeast Brazil: Mothers' health careseeking behaviors during their infants' fatal illness. Social Science \& Medicine 51(11): 1675-1693.

Walzer, M. 1984. Spheres of justice: A defense of pluralism and equality. New York: Basic Books.

Watts, J. 2016. Brazil's health system woes worsen in economic crisis. The Lancet 387(10028): 1603-1604.

Weeks, S. 2019. Portugal in ruins: From "Europe" to crisis and austerity. Review of Radical Political Economics 51(2): 246264.

Weinstock, D. 2014. Conscientious refusal and health professionals: Does religion make a difference? Bioethics 28(1): $8-15$.

World Health Organization (WHO). 2020. Portugal. http://www. who.int/countries/prt/en/.

Publisher's note Springer Nature remains neutral with regard to jurisdictional claims in published maps and institutional affiliations. 